УДК 582.579.2: 615.32

\title{
ФАРМАКОЛОГО-БИОХИМИЧЕСКОЕ ОБОСНОВАНИЕ ПРАКТИЧЕСКОГО ИСПОЛЬЗОВАНИЯ НЕКОТОРЫХ ПРЕДСТАВИТЕЛЕЙ РОДА IRIS L. (ОБ3ОР)
}

\author{
(ㄷ) Л.И. Тихомирова ${ }^{l^{*}}$, Н.Г. Базарнова ${ }^{1}$, И.В. Микушина ${ }^{1}$, З.В. Долганова ${ }^{2}$ \\ ${ }^{1}$ Алтайский государственный университет, пр. Ленина, 61, Барнаул, 656049, \\ (Pocсия), e-mail: L-tichomirova@yandex.ru \\ ${ }^{2}$ НИИ садоводства Сибири им. М.А. Лисавенко, Змеиногорский тракт, 49, \\ Барнаул, 656045 (Россия)
}

В обзоре приведены данные о местах естественного произрастания, ботаническое описание, химический состав, сведения об использовании в фармакологии лекарственного растительного сырья представителей Iris L.

В официальной и народной медицине используют листья, корневища и корни Iris lactea Pall., Iris pseudacorus L., Iris germanica L., Iris florentina L., Iris pallida Lam., Iris sibirica L., Iris setosa Pall., Iris ensata Tnunb. в виде сборов, лечебных и косметических средств. На основании комплексных исследований лекарственного растительного сырья Iris lactea, проведенных в Санкт-Петербургской химико-фармацевтической академии, созданы и апробированы уникальные препараты лечебно-профилактического действия «Витонк» и «Лактир». НПО «ВИЛАР» в настоящее время выпускается «Алпизарин» (ФС 42-2843-92).

Получен патент на изобретения, где используют каллусную культуру I. sibirica, как альтернативный способ получения лекарственного растительного сырья для получения эфирного масла. Предлагаемый способ обеспечивает улучшение качества эфирного масла, значительное повышение выхода ирона, снижение себестоимости получаемого продукта, возможность непрерывного выращивания культур тканей независимо от природных условий, расширение сырьевой базы.

Данные обзора послужат основой для дальнейшего изучения минерального состава, физиологически активных веществ, фармакологической эффективности данных видов Iris L. и разработки биотехнологий получения нового вида лекарственного растительного сырья Российской Федерации как одного из источников создания лечебных и профилактических средств современной медицины.

Ключевые слова: Iris L., химический состав, лекарственные средства, биологически активные вещества, лекарственное растительное сырье.

В современной медицине разрешено к использованию около 300 видов лекарственных растений. В России произрастает около 20 тысяч видов высших растений. Химически изучены примерно 5-6 тысяч видов. Перспективы работ по поиску и изучению лекарственных средств из растительного сырья огромны.

Тихомирова Людмила Ивановна - заведующая отделом биотехнологий растений Южно-Сибирского ботанического сада, кандидат биологических наук, e-mail: L-tichomirova@yandex.ru

Базарнова Наталья Григорьевна - заведующая кафедрой органической химии, доктор химических наук, профессор, e-mail: bazarnova@chem.asu.ru

Микушина Ирина Владимировна - доцент кафедры органической химии, кандидат химических наук, e-mail: mikuschinai@mail.ru

Долганова Зоя Владимировна - главный научный сотрудник, доктор сельскохозяйственных наук, професcop, e-mail: niilisavenko@ @otbox.ru
Род Iris L. включает в себя более чем 300 видов, произрастающих в Европе, Азии, Северной Америке, Северной Африке [1]. Лекарственное растительное сырье Iris L. используют для изготовления лекарственных и косметических средств [2-7].

В народной медицине широко используются виды Iris L. В Индии корневище употребляют как вяжущее, слабительное и мочегонное средство. В европейских странах - как потогонное, отхаркивающее и слабительное. В России отвар из корне-

\footnotetext{
* Автор, с которым следует вести переписку.
} 
вищ принимают при лечении бронхита. Размолотое сухое корневище используют при изготовлении различных лекарственных средств [8-10].

Цель работы - обобщить сведения научной литературы о химическом составе и способах практического использования растительного сырья видов Iris L. для изыскания наиболее перспективных направлений дальнейшего изучения представителей данного рода в области фармакогнозии и биотехнологии получения лекарственного сырья.

Ирис молочно-белый (Iris lactea Pall.). Плотнодерновинное растение. Основание побегов с жесткими темно-коричневыми, нитевидно расщепленными остатками влагалищ. Стебли многочисленные, 1020 см высотой. Прикорневые листья 15-20 см длиной, 3-5 мм шириной, сизо-зеленые. Листочки обверток в соцветии широкопленчатые, при плодах бумагообразные, обычно не достигают основания коробочек. Цветков 1-2, бледно-голубых, реже белых. Наружные доли околоцветника наиболее широкие в средней части отгиба, торчат кверху и мало отличаются по ширине от внутренних. Коробочка 3-6 см длиной, веретеновидная или продолговатая. Встречается на солонцеватых берегах рек и озер, засоленных сухих лугах, в чиевниках. Образует заросли в районах Сибири, на Дальнем Востоке, в Восточной Монголии, в СевероВосточном Китае [11].

Химический состав. Из надземной части ириса молочно-белого выделены 22 вещества. Из них 9 относятся к флавонам, 4 - к ксантонам и 9 - к фенолкарбоновым кислотам. Количественное содержание флавоноидов в сырье колеблется в пределах 4,38-7,40\%, содержание ксантонов - в пределах 0,54-1,05\%, мангиферина - 0,11-0,38\% [12, 13].

Фармакология. В надземной части растения обнаружено большое количество полифенольных соединений, в частности ксантонов, в состав которых входит мангиферин (алпизарин). Алпизарин (ФС 422843-92) в настоящее время выпускается ПЭЗ НПО «ВИЛАР» в виде таблеток $(0,1$ г) и 5 и $2 \%$ мази в тубах по 10 и 20 г в качестве противовирусного средства при герпесе. В надземной части касатика молочнобелого найдены также флавоновые С-гликозиды: производные апигенина и лютеолина, такие как эмбинин и его ацетаты [14].

Касатик молочно-белый содержит комплекс полифенольных соединений. Исследования, проведенные на кафедрах фармакогнозии и фармакологии Санкт-Петербургской химико-фармацевтической академии (СПХФА), позволили установить антигипоксическую и иммунотропную активность экстракта касатика [15-19].

Разработан способ получения комплекса, обладающего противовоспалительным, иммуномодулирующим и антигипоксическим действием. Получают средство путем экстракции из растительного сырья. В качестве сырья используют траву касатика молочно-белого, экстракцию проводят 35-45\% водным этанолом в течение 10-12 ч при соотношении сырье : экстрагент $1:(10-12)$. Экстракты объединяют, концентрируют и сушат с получением целевого комплекса. Полученный комплекс, обладая низкой токсичностью (ЛД50 = 7000 мг/кг), проявляет более высокую противовоспалительную и антигипоксическую активность [20-26].

Петербургскими фармакологами создан и апробирован уникальный препарат лечебнопрофилактического действия «Витонк», основу которого составляет экстракт надземной части ириса молочно-белого. Это растение содержит соединения, которые активизируют кроветворение, обладают противовоспалительными свойствами, повышают устойчивость организма к инфекциям [27].

На основании комплексных исследований, проведенных в Санкт-Петербургской химикофармацевтической академии, предложен также препарат «Лактир», представляющий собой таблетки сухого экстракта ириса молочно-белого. В результате фармакологических исследований препарат рекомендован в качестве противовоспалительного средства с иммуномодулирующей активностью для лечения больных с острыми и хроническими заболеваниями, в том числе аутоиммунной природы [20, 27-32].

I. lactea Pall. используется тибетскими медиками при воспалении легких, бронхитах, желтухе, хронических гастритах [33, 34].

Ирис болотный (Iris pseudacorus L.). Многолетнее растение высотой 50-100 см с толстым ветвистым корневищем. Геофит. Стебель прямостоячий, сжато-цилиндрический, вверху ветвистый. Нижние листья линейно-мечевидные, верхние линейно-ланцетные, шириной 1-3 см, ярко-зеленые. Цветки собраны в кистевидное соцветие или одиночные верхушечные, желтые, прицветники травянистые, длиннее завязи. Околоцветник из шести листочков, наружные листочки посередине с оранжевым пятном и сетью темных жилок, яйцевидные, суженные в ноготок; внутренние линейные, прямостоячие, короче рылец. Цветет с мая по июль. Плод - продолговатая, тупотрехсторонняя и многосемянная коробочка. Растет по берегам водо- 
емов, в прибрежном кустарнике, ольшаниках, в светлых лесах и на сырых лугах. Европейскозападноазиатский прибрежно-болотный вид может нередко достигать одного метра в высоту. Красивые золотисто-желтые цветки украшены коричневыми штрихами. Данное растение считается теплолюбивым и зимостойким, оно предпочитает прямые солнечные лучи. Его можно нередко встретить в любой точке Европы, в Сибири, на Дальнем Востоке, в Китае и Японии [35].

Изучено морфолого-анатомическое строение корней и корневищ Iris pseudacorus [36].

Химический состав. На основе современных технологий поиска перспективных растительных источников биологически активных соединений в лекарственном растительном сырье Iris pseudacorus выделен ряд соединений. Листья и корневища накапливают преимущественно вещества фенольной природы: флавоноиды, изофлавоноиды, дубильные вещества, ксантоны [37-43]. Методом колоночной хромотографии на силикагеле из хлороформной и этилацетатной фракции корневищ ириса болотного было выделено семь производных кумарина: кумарин, умбеллиферон, герниарин, дафноретин, эскулетин, скополетин, изоскополетин [44-47]. Приведены результаты исследования липофильных соединений листьев ириса болотного. В результате проведенного хроматографического анализа установлено наличие каротиноидов, токоферолов и хлорофиллов. Определен жирнокислотный состав липофильной фракции листьев ириса болотного и установлено наличие антимикробной активности [48, 49]. Определен компонентный состав эфирных масел корневищ и листьев ириса болотного Iris pseudacorus L. В первом из них обнаружено 29 соединений, во втором - 24; идентифицировано 17 и 20 компонентов соответственно; среди них терпеноиды, углеводороды, ароматические соединения. Установлено, что основными компонентами эфирного масла корневищ ириса болотного являются сквален (21\%), $\gamma$-куркумен $(5,8 \%)$, склареол $(2 \%)$, эвгенол $(6,6 \%)$. В листьях обнаружены линалоол $(2,4 \%)$, сквален (26\%), $\alpha$-мууролен $(1 \%), \alpha$ - и $\beta$-эудесмолы $(2,8 \%)$ [50]. Кроме данных соединений, выделены ароматические, терпеноиды и аминокислоты [51, 52].

Фармакология. Результаты исследований свидетельствуют о наличии фармакологической активности экстрактов I. pseudacarus, в частности установлен анаболический и адаптогенный эффекты [53].

В качестве объекта исследования были взяты сухие гидрофильные экстракты I. pseudacarus. Уникальный фитохимический состав сухих гидрофильных экстрактов I. pseudocarus включает в себя 19 соединений полифенольной природы, что обеспечивает разнообразие терапевтических эффектов [54, 55]. Выявлена антимикробная активность экстрактов Iris pseudacorus [56]. Приведены результаты экспериментального изучения диуретической активности и острой токсичности сухого гидрофильного экстракта I. pseudacorus. Анализ экспериментальных данных показал, что исследуемый сухой гидрофильный экстракт листьев ириса болотного проявляет выраженную диуретическую активность, которая превышает активность растительного препарата сравнения ортосифона, но уступает по активности синтетическому препарату сравнения фуросемиду. Проведенные токсикологические исследования сухого гидрофильного экстракта листьев ириса болотного на двух видах животных позволили установить отсутствие токсикологического влияния на организм животных и отнести их к классу практически нетоксичных веществ. Субстанция сухого гидрофильного экстракта I. pseudacorus является перспективной для дальнейшего изучения с целью создания на его основе новых лекарственных средств [57].

Известно применение I. pseudacorus L., корневища которого входят в состав сбора М.Н. Здренко, используемого в онкологической практике [58].

Изобретен способ приготовления противоожогового средства. В предлагаемом способе в качестве сырья используют измельченный корень I. pseudacorus при соотношении сырье : масло = $1: 24$, настаивание проводят в течение 14 дней в темном помещении. Предлагаемое противоожоговое средство может быть применено для лечения длительно не заживающих ожогов, ран, порезов, раздражения, трещин и опрелостей на коже, эрозии, чирьев, морщин (в том числе в пластической хирургии для послеоперационного заживления кожи), а также простудных заболеваний (ангины, насморка). Кроме того, заявляемый состав применяется в качестве обезболивающего и кровоостанавливающего средства [59].

Ирис германский (Iris germanica L), ирис флорентийский (I. florentina L.), ирис бледный (I. pallida Lam.). Все три вида - многолетние травянистые растения с крупным косорастущим маловетвистым корневищем, снабженным с нижней стороны многочисленными корнями. На верхушке корневища образуются 4-6 листьев. У ириса германского цветки темно-фиолетовые, у и. флорентийского - белые, у и. бледного - светло-фиолетовые, душистые. Корневища их сходны между собой. Все три вида ирисов, 
естественно, произрастают преимущественно в Средиземноморье. В лекарственных целях и для парфюмерной промышленности культивируются в СНГ, Италии, Франции и ряде других стран [60].

Стандартизаиия. Входит в БТФ и фармакопеи ряда европейских государств.

Химический состав. Корневище содержит 0,1-0,2\% эфирного масла. Масло при обычной температуре плотное; из него можно выделить 80-90\% кислоты миристиновой, не обладающей запахом, и 10-29\% носителей запаха, среди которых основным является кетон ирон. Ирон представляет собой смесь трех изомеров: $\alpha-, \beta-, \gamma$-иронов. Кроме ирона, аромат эфирному маслу придают следы бензальдегида, линалоола, гераниола и др.

Фармакология. В Индии употребляют как вяжущее, слабительное и мочегонное средство; в европейских странах - как потогонное, отхаркивающее, слабительное и болеутоляющее средство [61, 62].

Антиоксидантные свойства водного и спиртового экстрактов I. germanica исследованы in vitro c использованием различных тестов на восстановительную способность, антирадикальную активность (в отношении свободных, перекисных и супероксидных радикалов) и хелатообразование. Оба экстракта показали высокую антиоксидантную активность, ингибируя модельную реакцию перекисного окисления в суспензии линолеиновой кислоты на 95,9, 88,4 и 79,9\% (водный) и 90,5, 78,0 и 65,3\% (спиртовой) при концентрации в растворе 10,30 и 50 мкг/мл соответственно. Эффективное подавление радикальных процессов и образование хелата железа наблюдалось при концентрации растворов 20, 40 и 60 мкг/мл. Антиоксидантные свойства водного и спиртового экстрактов ириса в модельных реакциях были сравнимы со свойствами ряда стандартных препаратов, включая $\alpha$-токоферол, бутилгидроксианизол и бутилгидрокситолуол. Определено суммарное содержание фенольных веществ в экстрактах ириса (в пересчете на галловую кислоту). Высказано предположение, что антиоксидантные свойства, проявленные экстрактами ириса in vitro, могут объяснять их способность к ингибированию перекисного окисления липидов [63].

Ирис сибирский (I. sibirica L.). Многолетнее растение. Корневище вверху с бурыми остатками листовых влагалищ. Стебель вверху разветвленный, с 2-3 стеблеобъемлющими листьями. Прикорневые листья линейные, до 50-80 см длиной. Листочки обвертки ланцетные, травянистые. Цветки в числе 2-3, на неравных цветоножках, с короткой трубкой околоцветника, темно-синие. Наружные доли околоцветника, так же как и внутренние, синие, с бледно-синим ноготком. Коробочка 2-3 см длиной, тупая. Семена светло-серые, плоско сдавленные. Ареалом его распространения являются огромные территории, начиная от севера Италии и до чистейшего озера Байкал. Популяции растения также встречаются в Республике Коми, на Кавказе и в Северной Турции [60].

Химический состав. Подземная часть содержит углеводы (сахароза - до 2,3\%, фруктаны - до 2,7\%, крахмал - до 2,5\%). В листьях найдены фенолкарбоновые кислоты (кофейная, синаповая, $n$-кумаровая, феруловая); флавоноиды (кверцетин, мирицетин); антоцианы (дельфинидин, цианидин). Семена содержат глюкоманнаны - до 18\%. Известен способ получения эфирного масла из каллусной культуры I. sibirica. Использование предлагаемого способа обеспечивает улучшение качества эфирного масла, значительное повышение выхода ирона, снижение себестоимости получаемого продукта, возможность непрерывного выращивания культур тканей независимо от природных условий, расширение сырьевой базы [64-66].

Фармакология. Отвар используют при болезнях сердца, а также как ранозаживляющее средство. Подземная часть применяется при водянке, сифилисе, цинге, как кровоостанавливающее, слабительное, антигельминтное средство. Отваром и настоем корневищ полощут ротовую полость при абсцессах горла, зубной боли. Подземная часть, цветки, семена применяются в тибетской медицине при пневмониях, бронхитах, гепатитах, хронических гастритах, женских болезнях.

Ирис щетинистый (I. setosa Pall.). Многолетнее травянистое растение. Корневище с остатками расщепленных листовых влагалищ. Стебель ветвистый, длиннее листьев. Листья более 10 мм шириной, мечевидные. Листочки обвертки зеленые или со слабым фиолетовым оттенком, по краям окаймленные. Цветков 2-3. Наружные доли околоцветника широко-яйцевидные, резко переходящие в короткий ноготок; внутренние до 2 см длиной, широкие, круто суженные в ланцетное острие, которое превышает длину основания. Коробочка трехугольная, сильно вздутая. Семена косо-яйцевидные, темно-коричневые, лоснящиеся. Встречается по берегам водоемов, болотам, на открытых участках и в зарослях кустарников Красноярского края, Иркутской области, Якутии, на Дальнем Востоке, в Китае, на Корейском полуострове, в Японии и Северной Америке (приморская полоса Аляски, Алеутские острова) [60]. 
Химический состав ириса щетинистого не изучен, известно лишь, что в надземной части и плодах содержатся флавоноиды, в корневище идентифицирован один из них- иридин [67].

Фармакология. А.И. Шретер [67] сообщает, что в японской народной медицине порошок корневищ использовали при чесотке, а в Якутии корневища применяли как болеутоляющее при зубных болях и рвотное, а цветки - наружно при нарывах [68].

Ирис мечевидный (I. ensata Tnunb.). Многолетнее травянистое растение. Высота узких листьев не превышает 40 см. Плоские цветки имеют короткие внутренние и довольно широкие наружные лепестки. Средняя высота цветоносов составляет не более 70 см. В природных условиях всегда цветет с середины июля и до середины августа. Мечевидный ирис с особым утолщенным корневищем встречается в Корее, Китае и Японии [60].

Химический состав. К.Ф. Блинова и ее коллеги $[69,70]$ выделили ксантоновые гликозиды. В частности, определено содержание ксантонового гликозида мангиферина у некоторых растений родов Iris, в том числе у I. ensata [71].

Фармакология. Ирис I. ensata применяется в парфюмерном и кондитерском производствах; используется в косметике для устранения веснушек и морщин, годен для дубления кож, получения желтой краски, изготовления веревок, щеток, циновок. Является хорошим антисептиком, используется при укусах ядовитых насекомых и змей [67]. Но самое широкое применение ирис мечевидный, по сравнению с другими дальневосточными ирисами, имеет в медицине, в том числе народной. В китайской и тибетской медицине используются все части растения - корни, листья, цветки, плоды. Выявлено антибактериальное действие препаратов из ириса в отношении микобактерий туберкулеза [72].

\section{Выводы}

1. Проведен обзор доступных литературных данных в области химического состава и путей использования Iris L. (Iris lactea Pall., Iris pseudacorus L., Iris germanica L., Iris florentina L., Iris pallida Lam., Iris sibirica L., Iris setosa Pall., Iris ensata Tnunb.) для изыскания наиболее перспективных направлений дальнейшего изучения представителей данного рода в области фармакогнозии.

2. В лекарственном растительном сырье Iris L. выделен ряд ценных биологически активных соединений.

3. В качестве сырья используют траву, корни и корневища в виде сборов, лечебных и косметических средств. Созданы и апробированы уникальные препараты лечебно-профилактического действия «Витонк», «Лактир», «Алпизарин» и др.

4. Данные обзора послужат основой для дальнейшего изучения минерального состава, физиологически активных веществ, фармакологической эффективности данных видов Iris L. и разработки биотехнологий получения нового вида лекарственного растительного сырья Российской Федерации как одного из источников создания лечебных и профилактических средств современной медицины.

\section{Список литературы}

1. Доронькин В.M. Систематика рода Iris L. (Iridaceae Juss.) Азиатской России // Роль ботанических садов в сохранении биоразнообразия растительного мира Азиатской России: настоящее и будущее. Новосибирск, 2006. C. 101-103.

2. Патент 2048802 (РФ). Крем для кожи / И.М. Долотовский, Л.3. Долотовская, А.Я. Шмелев, Т.Г. Гапечкина, И.Ю. Усманов. 1995.

3. Патент 2109506 (РФ). Средство для ухода за волосами / И.М. Долотовский, Л.З. Долотовская, А.Я. Шмелев, Т.Г. Гапечкина. 1998.

4. Патент 2062092 (РФ). Средство для ухода за кожей / И.М. Долотовский, Л.З. Долотовская, А.Я. Шмелев, Т.Г. Гапечкина, И.Ю. Усманов. 1996.

5. Патент 2101003 (РФ). Средство для ухода за кожей / И.М. Долотовский, Л.З. Долотовская, А.Я. Шмелев, Т.Г. Гапечкина. 1998.

6. Патент 2255107 (РФ). Бальзам «Ефимов» / В.М. Ефимов. 2003.

7. Патент 2122424 (РФ). Лекарственное средство «Савитам», обладающее общеукрепляющим действием / В.А. Мухина, В.И. Журавлев. 1998.

8. Виноградова Т.А., Гажев Б.Н., Виноградов В.Н., Мартынов В.К. Практическая фитотерапия. М. ; СПб., 2001. $640 \mathrm{c.}$

9. Ланина Н.Е., Пряхина Н.И., Лесиовская Е.Е., Минина С.А. К определению подлинности лекарственного растительного сырья травы касатика молочно-белого // Актуальные проблемы создания новых лекарственных препаратов природного происхождения : тезисы докл. VI Междунар. съезда. СПб., 2002. С. 66. 
10. Пастушенков Л.В., Фролова Н.Ю., Мельникова Т.Н. Фармакологическое изучение экстракта касатика // Состояние и перспективы развития фармации в Сибири и на Дальнем Востоке. Томск, 1991. С. 82-83.

11. Пряхина Н.И. Фитохимическое изучение касатика молочно-белого : автореф. дис. ... канд. фарм. наук. Л., 1984. $25 \mathrm{c}$.

12. Минина С.А. Общая характеристика гликозидов. Химическая структура, свойства и технология флавоновых гликозидов и сапонинов. СПб., 1992. 40 с.

13. Chosal S., Biswas K., Chaudhurie R.K. Chemical constifuents of gentianaceae XXVI: Anti-mycobacterium tuberculosis activity of naturally ocuring xanthones // J. Pharm. Sci. 1978. Vol. 67, N5. Pp. 721-722.

14. Минина С.А., Абу Схела Г.Р., Астахова Т.В., Пряхина Н.И., Зенкевич И.Г., Косман В.М. Технология получения сухого экстракта из надземной части касатика молочно-белого // Химико-фармацевтический журнал. 1999. №4 (33). С. 40-42.

15. Астахова Т.В., Пряхина Н.И., Ланина Н.Е., Зажигалкина М.В., Чемесова И.И. Разработка метода стандартизации сиропа с экстрактом касатика молочно-белого // Актуальные проблемы фармацевтической науки и образования. Пермь, 2000. С. 170-171.

16. Баринов Е.А., Горанчук В.В., Пастушенков В.Л., Галицкий А.Н. Растительный препарат суммарный экстракт касатика молочно-белого и его адаптогенные свойства при экстремальной тепловой нагрузке // Медицинское обеспечение мобильных сил. СПб., 1997. С. 14-15.

17. Баринов Е.А., Пастушенков В.Л., Мельникова Т.И., Сапегин А.А. Изучение иммунометаболических свойств экстракта касатика молочно-белого // Актуальные вопросы клиники, диагностики и лечения. СПб., 1995. 551 с.

18. Баринов Е.А., Пастушенков В.Л., Сапегин А.А. Новый иммуномодулирующий препарат экстракт касатика молочно-белого // Актуальные вопросы военно-морской и клинической медицины. СПб., 1995. 205 с.

19. Панина Н.Е., Минина С.А., Пряхина Н.И. Исследование химического состава настойки и шрота из травы касатика молочно-белого // Растительные ресурсы. 2003. №3. С. 99-105.

20. Патент 2123349 (РФ). Способ получения комплекса, обладающего противовоспалительным, иммуномодулирующим и антигипоксическим действием / С.А. Минина, Т.В. Астахова, Н.И. Пряхина, Л.В. Пастушенков, Е.Е. Лесиовская, Т.И. Мельникова, Н.Ю. Фролова, В.А. Вавилова. 20.12.1998.

21. Фролова Н.Ю., Пастушенков Л.В., Мельникова Т.И., Плацен Р.И. Новые свойства экстракта касатика // Реализация научных достижений в практической фармации : тезисы респуб. конференции. Харьков, 1991. С. 249.

22. Фролова Н.Ю., Мельникова Т.И., Плацен Р.И. Фармакологическая оценка полиэкстракта касатика молочнобелого // Тезисы 3-й украинской конференции по медицинской ботанике. Киев, 1992. С. 139.

23. Фролова Н.Ю., Мельникова Т.И. Возможные механизмы антигипоксического эффекта экстракта касатика // Фармакологическая коррекция гипоксических состояний : тезисы 2-й Всесоюзной конференции. Гродно, 1991. С. 252-253.

24. Пастушенков Л.В., Фролова Н.Ю., Мельникова Т.И., Пряхина Н.И., Астахова Т.В., Блинова К.Ф., Плацен Р.И. Фармакологическое изучение экстракта касатика // Состояние и перспективы развития фармации в Сибири и на Дальнем Востоке. Томск, 1991. С. 82-83.

25. Минина С.А., Абу Схела Г.Р., Астахова Т.В., Пряхина Н.И., Зенкевич И.Г., Косман В.М. Технология получения сухого экстракта из надземной части касатика молочно-белого // Химико-фармацевтический журнал. 1999. №4 (33). C. 40-42.

26. Баринов Е.А. Изучение иммуномодулирующих и адаптогенных эффектов сухого экстракта касатика молочнобелого при гипоксии и гипертермии : автореф. дис. ... канд. мед. наук. СПб., 1999. 25 с.

27. Мельникова Т.И. Фармакологическое изучение суммарного экстракта касатика молочно-белого : автореф. дис. ... канд. биол. наук. СПб., 1994. 20 с.

28. Минина С.А., Пряхина Н.И., Чижиков Д.В., Чемесова И.И. Детский лекарственный препарат с экстрактом касатика молочно-белого // Химико-фармацевтический журнал. 2008. №1. С. 39-41.

29. Минина С.А., Астахова Т.В., Пряхина Н.И., Абу Схела Г. Выбор состава и разработка технологии получения таблеток экстракта касатика молочно-белого // Химико-фармацевтический журнал. 2001. Т. 35. С. $24-26$.

30. Фролова Н.Ю., Мельникова Т.И. Результаты доклинических испытаний нового фитопрепарата лактир // Актуальные проблемы создания новых лекарственных средств : тезисы докл. науч. конф. СПб., 1996. С. 175.

31. Мельникова Т.И., Фролова Н.Ю. Возможности использования препарата лактир при хронической почечной недостаточности // Актуальные проблемы создания новых лекарственных средств : тезисы докл. науч. конф. СПб., 1996. С. 147.

32. Литвинович Ж.В. Разработка технологии и анализ детских лекарственных форм на основе сухого экстракта касатика молочно-белого // Молодая фармация : сборник научных работ СПХФА. СПб., 1998. Вып. 1. С. 82-85.

33. Носаль М.А., Носаль И.М. Лекарственные растения и способы их применения в народной медицине. Л., 1991. C. 23-25.

34. Грубов В.И. Критические заметки по таксономии и номенклатуре некоторых видов ириса. Флора СССР. Новости систематики высших растений. М., 1970. Т. 6. С. 29-37.

35. Миронова Л.Н., Зайнетдинова Г.С. Выращивание и размножение ириса желтого в связи с интродукцией в Республике Башкортостан // Сельскохозяйственная биология. 2009. №5. С. 40-44.

36. Ковальов В.М., Сербін А.Г., Краснікова Т.О., Кічимасова Я.С., Затильнікова О.О., Ковальов С.В. Морфологоанатомічне дослідження кореневищ з коренями Iris pseudacorus // Фармацевтичний журнал. 2008. №4. С. $99-102$.

37. Khare C.P. Indian medicinal plants. Berlin; Heidelberg, 2007. 836 p.

38. Tsukasa I. Flavonoids of the genus Iris; structures, distribution and function // Ann. Tsukuba Bot. Gard. 1998. Vol. 17. Pp. 147-183.

39. Boland G.M., Dervilla M.X. Donnelly Isoflavonoids and related compounds // Natural Product Reports. 1998. Pp. 241-260.

40. Затыльникова О.А., Ковалев С.В. Фитохимическое изучение Iris pseudacorus // Фармация Казахстана: интеграция науки, образования и производства : матер. Межд. научн.-практ. конф. Шимкент, 2009. С. 225-228. 
41. Williams Ch.A., Harborne J.B., Colasante M. Flavonoid and xanthone patterns in bearded Iris species and the pathway of chemical evolution in the genus // Biochemical Systematics and Ecology. 1997. Vol. 25, N4. Pp. 309-325.

42. Исаев Д.И., Керимов Ю.Б., Ковалев С.В., Затыльникова О.А. Ксантоны корневищ Iris imbricate и Iris pseudacorus // Фармаком. 2009. №4. С. 45-48.

43. Ковалева А.М., Горячая О.В., Ильина Т.В., Седова А. Б. Современные информационные технологии в поиске перспективных растительных источников биологически активных соединений // Вестник Пермской государственной фармацевтической академии. Современные тенденции и перспективы развития фармацевтического образования и науки в России и за рубежом : матер. науч.-практ. конф. с междун. участ. 2013. №11. С. 74-76.

44. Ковалёв С.В., Михайленко О.А., Ковалёв С.В. Кумарины ириса болотного (Iris Pseudocarus L.) // Химия растительного сырья. 2013. №3. С. 201-205.

45. Исаев Д.И., Керимов Ю.Б., Ковалев С.В., Затыльникова О.А. Изофлавоноиды корневищ Iris imbricate и Iris pseudacorus // Фармаком. 2010. №1. С. 38-42.

46. Ковалев В.Н., Затыльникова О.А., Ковалев С.В. Новый изофлавон из Iris pseudacorus // Химия природных соединений. 2013. №1. С. 32-33.

47. Kovalev V.N., Zatylnikova O.A., Kovalev S.V. New Isoflavone from Iris pseudacorus // Chemistry of Natural Compounds. Springer Link. 2013. Vol. 49, issue 1. Pp 34-35.

48. Затильнікова О.О. Дослідження ліпофільної фракції з листя Iris pseudacorus // Вісник фармації. 2012. №3 (71). C. 57-59.

49. Ковальов С.В., Осолодченко Т.П., Ахмедов Е. Ю., Затильнікова О.О. Хімічне вивчення ліпофільної фракції $з$ кореневища півників болотяних // Вісник фармації. 2008. №3 (55). С. 9-12.

50. Затыльникова О.А., Ковалев В.Н., Ковалев С.В. Компонентный состав эфирных масел Iris pseudacorus (Iridaceae // Растительные ресурсы. 2013. Т. 49, №2. С. 233-240.

51. Затильнікова О.О., Ковальов С.В. Вивчення амінокислотного та мінерального складу підземних органів Iris pseudacorus L. // Фармаком. 2009. №1. С. 45-47.

52. Ковалев В.Н., Михайленко О.А., Виноградов Б.А. Ароматические соединения и терпеноиды Iris hungarica // Химия природных соединений. 2014. №1. С. 143-144.

53. Хохлова Н.А., Деркач Н.В., Затыльникова О.А. Влияние сухих гидрофильных экстрактов ириса на показатели белкового обмена // Укр. біофарм. журн. 2010. №3 (8). С. 45-47.

54. Лікарські рослини: [енциклопед. довід.] / За ред. А.М. Гродзинського. Киев, 1990. 544 с.

55. Хохлова Н.А., Деркач Н.В., Затыльникова О.А., Ковалев В. Н., Волковой В.А. Фармакологическое изучение Iris pseudacorus // Український біофармацевтичний журнал. 2012. №1-2 (18-19). С. 42-45.

56. Затильнікова О.О., Осолодченко Т.П., Ковальов В.М. Антимікробна активність екстрактів з Iris pseudacorus L. // Анали Мечниковського Інституту. 2010. №4. С. 43-47.

57. Хохлова Н.А., Деркач Н.В., Затыльникова О.А., Ковалёв В.Н., Волкова В.А. Фармакологическое изучение I. pseudocorus L. // Укр. біофарм. журн. 2012. №1-2. С. 42-45.

58. Яковлев Г.П., Блинова К.Ф. Ботанико-фармакогностический словарь. М., 1990. 192 с.

59. Патент 2195307 (РФ). Противоожоговое средство и способ его приготовления / С.А. Васильева, В.В. Васильев, О.Ю. Седова. 2002.

60. Тахтаджян А.Л., Фёдоров А.А. Жизнь растений : в 6 т. Т. 6 : Цветковые растения. М., 1982. 543 с.

61. Иорданов Д., Николов П. Фитотерапия. София, 1970. 183 с.

62. Evans W.C. Trease aand Evans. Pharmacognosy. $14^{\text {th }}$ Edition. London, 1996, 612 p.

63. Надароглу Х., Демир Я., Демир Н. Антиоксидантные и антирадикальные свойства экстракта из Iris germanica. // Химико-фармацевтический журнал. 2007. Т. 41, №8. С. 13-18.

64. Асланянц Л.К., Маршавина 3.В. Об эфирном масле, синтезируемом культурой ткани ириса Iris sibirica // Прикладная биохимия и микробиология. 1979. Т. 15. С. 769-774.

65. Асланянц Л.К., Маршавина 3.В., Казарян А.Г. Продуктивность культуры клеток Iris sibirica L., выращенных на упрощенной питательной среде // Растительные ресурсы. 1988. Т. 24. С. 107-110.

66. Багдасарова 3.М., Асланянц JI.К., Узунян Л.В. Биоконверсия терпеноидов культурой клеток ириса (Iris sibirica) // Прикладная биохимия и микробиология. 1988. Т. 24. С. 774-778.

67. Шретер А.И. Лекарственная флора советского Дальнего Востока. М., 1975. 327 с.

68. Беркутенко А.Я., Романовский С.С. Редкие растения заповедника «Магаданский» (Ямский участок) // Современное состояние и перспективы научных исследований в заповедниках Сибири. М., 1986. С. 68-70.

69. Блинова К.Ф., Калюпанова Н.И. Ксантоновые гликозиды Iris ensata // Химия природных соединений. 1974. №4. C. 535.

70. Блинова К.Ф., Глызин В.И., Пряхина Н.И. С-гликозид из Iris ensata // Химия природных соединений. 1977. №1. C. 535.

71. Денисова О.А., Глызин В.И., Патудин А.В., Гавриленко Б.Д. Определение содержания ксантонового гликозида мангиферина у некоторых растений родов Iris, Gentiana, Hedysarum // Химико-фармацевтический журнал. 1980. T. 14. C. 76-77.

72. Фруентов Н.К. Лекарственные растения Дальнего Востока. Хабаровск, 1987. 349 с. 
Tikhomirova L.I. ${ }^{*}$, Bazarnova N.G. ${ }^{1}$, Mikushina I.V. ${ }^{1}$, Dolganova Z.V. ${ }^{2}$ FARMACOL-BIOCHEMICAL STUDY OF PRACTICAL USE OF SOME MEMBERS OF THE GENUS IRIS L. (OVERVIEW)

${ }^{1}$ Altai State University, Lenina st., 61, Barnaul, 656049 (Russia), e-mail: L-tichomirova@yandex.ru

${ }^{2}$ M.A. Lisavenko Scientific Research Institute of Horticulture for Siberia, Zmeinogorskii trakt, 49, Barnaul, 656045

(Russia)

The overview provides information about places of natural habitat, Botanical description, chemical composition, information about the use of pharmaceuticals, medicinal plants of representatives Iris $\mathrm{L}$.

In official and folk medicine uses the leaves, rhizomes and roots of Iris lactea Pall., Iris pseudacorus L., Iris germanica L., Iris florentina L., Iris pallida Lam., Iris sibirica L., Iris setosa Pall., Iris ensata Tnunb. in the form of fees, medical and cosmetic products. On the basis of comprehensive studies of medicinal plants of Iris lactea, held in Saint-Petersburg chemical-pharmaceutical Academy, created and tested unique drugs preventive action "Viton" and "Latter". NGO "VILAR" currently available "Alpizarin" (FS 42-2843 - 92).

Received a patent for inventions where the use of callus culture I. sibirica, as an alternative method of obtaining medicinal plant materials to produce essential oil. The proposed method enhances the quality of essential oil, a significant increase in the output of iron, reducing the cost of the resulting product, the possibility of continuous cultivation of tissues regardless of environmental conditions, the expansion of the resource base.

Survey data will serve as a basis for further study of the mineral composition of physiologically active substances, pharmacological effectiveness data Iris L. and development of biotechnology receipt of a new kind of medicinal plant resources of the Russian Federation, as a source of creating therapeutic and prophylactic drugs in modern medicine.

Keywords: Iris L., chemical composition, medicines, biologically active substances, medicinal plant raw material.

\section{References}

1. Doron'kin V.M. Rol' botanicheskikh sadov v sokhranenii bioraznoobraziia rastitel'nogo mira Aziatskoi Rossii: nastoiashchee i budushchee. [The role of botanic gardens in the conservation of biodiversity of flora of Asian Russia: present and future]. Novosibirsk, 2006, pp. 101-103. (in Russ.).

2. Patent 2048802 (RU). 1995. (in Russ.).

3. Patent 2109506 (RU). 1998. (in Russ.).

4. Patent 2062092 (RU). 1996. (in Russ.).

5. Patent 2101003 (RU). 1998. (in Russ.).

6. Patent 2255107 (RU). 2003. (in Russ.).

7. Patent 2122424 (RU). 1998. (in Russ.).

8. Vinogradova T.A., Gazhev B.N., Vinogradov V.N., Martynov V.K. Prakticheskaia fitoterapiia. [Practical herbal medicine.]. Moscow ; St. Petersburg, 2001, 640 p. (in Russ.).

9. Lanina N.E., Priakhina N.I., Lesiovskaia E.E., Minina S.A. Aktual'nye problemy sozdaniia novykh lekarstvennykh preparatov prirodnogo proiskhozhdeniia: tezisy dokl. VI mezhdunar. s"ezda. [Actual problems of creating new drugs of natural origin: abstracts of the VI International Congress]. St. Petersburg, 2002, p. 66. (in Russ.).

10. Pastushenkov L.V., Frolova N.Iu., Mel'nikova T.N. Sostoianie i perspektivy razvitiia farmatsii v Sibiri $i$ na Dal'nem Vostoke. [Status and prospects of development of pharmacy in Siberia and the Far East]. Tomsk, 1991, pp. 82-83. (in Russ.).

11. Priakhina N.I. Fitokhimicheskoe izuchenie kasatika molochno-belogo : avtoref. dis. ... kand. farm. nauk. [Phytochemical study of iris milky white: dissertation of the candidate of pharmaceutical sciences]. Leningrad, 1984, 25 p. (in Russ.).

12. Minina S.A. Obshchaia kharakteristika glikozidov. Khimicheskaia struktura, svoistva i tekhnologiia flavonovykh glikozidov $i$ saponinov. [General characteristics of the glycosides. The chemical structure, properties and technology flavone glycosides and saponins]. St. Petersburg, 1992, 40 p. (in Russ.).

13. Chosal S., Biswas K., Chaudhurie R.K. J. Pharm. Sci., 1978, vol. 67, no. 5, pp. 721-722.

14. Minina S.A., Abu Skhela G.R., Astakhova T.V., Priakhina N.I., Zenkevich I.G., Kosman V.M. Khimikofarmatsevticheskii zhurnal, 1999, no. 4 (33), pp. 40-42. (in Russ.).

15. Astakhova T.V., Priakhina N.I., Lanina N.E., Zazhigalkina M.V., Chemesova I.I. Aktual'nye problemy farmatsevticheskoi nauki i obrazovaniia. [Actual problems of pharmaceutical science and education]. Perm, 2000, pp. 170-171. (in Russ.).

16. Barinov E.A., Goranchuk V.V., Pastushenkov V.L., Galitskii A.N. Meditsinskoe obespechenie mobil'nykh sil. [Medical support mobile forces]. St. Petersburg, 1997, pp. 14-15. (in Russ.).

17. Barinov E.A., Pastushenkov V.L., Mel'nikova T.I., Sapegin A.A. Aktual'nye voprosy kliniki, diagnostiki i lecheniia. [Pressing questions of clinic, diagnostics and treatment]. St. Petersburg, 1995, 551 p. (in Russ.).

18. Barinov E.A., Pastushenkov V.L., Sapegin A.A. Aktual'nye voprosy voenno-morskoi i klinicheskoi meditsiny. [Topical issues of the naval and Clinical Medicine]. St. Petersburg, 1995, 205 p. (in Russ.).

19. Panina N.E., Minina S.A., Priakhina N.I. Rastitel'nye resursy, 2003, no. 3, pp. 99-105. (in Russ.).

20. Patent 2123349 (RU). 1998. (in Russ.).

21. Frolova N.Iu., Pastushenkov L.V., Mel'nikova T.I., Platsen R.I. Realizatsiia nauchnykh dostizhenii v prakticheskoi farmatsii: tez. respub. konferentsii. [The implementation of scientific achievements in the practice of pharmacy: Abstracts of the Republican Conference]. Kharkiv, 1991, p. 249. (in Russ.).

22. Frolova N.Iu., Mel'nikova T.I., Platsen R.I. Tezisy 3-i ukrainskoi konferentsii po meditsinskoi botanike. [Abstracts of the 3rd Ukrainian conference on medical botany]. Kiev, 1992, p. 139. (in Russ.).

\footnotetext{
* Corresponding author.
} 
23. Frolova N.Iu., Mel'nikova T.I. Farmakologicheskaia korrektsiia gipoksicheskikh sostoianii: tezisy 2-i Vsesoiuznoi konferentsii. [Pharmacological correction of hypoxic states : Abstracts $2^{\text {nd }}$ Union Conference]. Grodno, 1991, pp. 252-253. (in Russ.).

24. Pastushenkov L.V., Frolova N.Iu., Mel'nikova T.I., Priakhina N.I., Astakhova T.V., Blinova K.F., Platsen R.I. Sostoianie i perspektivy razvitiia farmatsii v Sibiri i na Dal'nem Vostoke. [Status and prospects of development of pharmacy in Siberia and the Far East]. Tomsk, 1991, pp. 82-83. (in Russ.).

25. Minina S.A., Abu Skhela G.R., Astakhova T.V., Priakhina N.I., Zenkevich I.G., Kosman V.M. Khimikofarmatsevticheskii zhurnal, 1999, no. 4 (33), pp. 40-42. (in Russ.).

26. Barinov E.A. Izuchenie immunomoduliruiushchikh i adaptogennykh effektov sukhogo ekstrakta kasatika molochnobelogo pri gipoksii i gipertermii : avtoref. dis. ... kand. med. nauk. [Study of immunomodulatory and adaptogenic effects of dry extract iris milky white in hypoxia and hyperthermia: the Dissertation of the candidate of medical sciences]. St. Petersburg, 1999, 25 p. (in Russ.).

27. Mel'nikova T.I. Farmakologicheskoe izuchenie summarnogo ekstrakta kasatika molochno-belogo : avtoref. dis. ... kand. biol. nauk. [Pharmacological study of the total extract of iris milky white: the Dissertation of the candidate of biological sciences]. St. Petersburg, 1994, 20 p. (in Russ.).

28. Minina S.A., Priakhina N.I., Chizhikov D.V., Chemesova I.I. Khimiko-farmatsevticheskii zhurnal, 2008, no. 1, pp. 39-41. (in Russ.).

29. Minina S.A., Astakhova T.V., Priakhina N.I., Abu Skhela G. Khimiko-farmatsevticheskii zhurnal, 2001, vol. 35, pp. 24-26. (in Russ.).

30. Frolova N.Iu., Mel'nikova T.I. Aktual'nye problemy sozdaniia novykh lekarstvennykh sredstv : tezisy dokl. nauch. konf. [Actual problems of development of new drugs: abstracts of scientific conference]. St. Petersburg, 1996, p. 175. (in Russ.).

31. Mel'nikova T.I., Frolova N.Iu. Aktual'nye problemy sozdaniia novykh lekarstvennykh sredstv: tezisy dokl. nauch. konf. [Actual problems of development of new drugs: abstracts of scientific conference]. St. Petersburg, 1996, p. 147. (in Russ.).

32. Litvinovich Zh.V. Molodaia farmatsiia: Sbornik nauchnykh rabot SPKhFA. [Young Pharmacy: Collection of scientific works of the St. Petersburg Chemical Pharmaceutical Academy]. St. Petersburg, 1998, issue. 1, pp. 82-85. (in Russ.).

33. Nosal' M.A., Nosal' I.M. Lekarstvennye rasteniia i sposoby ikh primeneniia v narodnoi meditsine. [Medicinal plants, and methods for their use in traditional medicine]. Leningrad, 1991, pp. 23-25. (in Russ.).

34. Grubov V.I. Kriticheskie zametki po taksonomii $i$ nomenklature nekotorykh vidov irisa. Flora SSSR. Novosti sistematiki vysshikh rastenii. [Critical Remarks on the taxonomy and nomenclature of some species of iris. Flora of the USSR. News of systematics of higher plants]. 1970, vol. 6, pp. 29-37. (in Russ.).

35. Mironova L.N., Zainetdinova G.S. Sel'skokhoziaistvennaia biologiia, 2009, no. 5, pp. 40-44. (in Russ.).

36. Koval'ov V.M., Serbin A.G., Krasnikova T.O., Kichymasova Ja.S., Zatyl'nikova O.O., Koval'ov S.V. Farmacevtychnyj zhurnal, 2008, no. 4, pp. 99-102. (in Ukr.).

37. Khare C.P. Indian medicinal plants. Berlin; Heidelberg, 2007. 836 p.

38. Tsukasa I. Ann. Tsukuba Bot. Gard., 1998, vol. 17, pp. 147-183.

39. Boland G.M., Dervilla M.X. Natural Product Reports, 1998, pp. 241-260.

40. Zathl'nykova O.A., Kovalev S.V. Farmacyja Kazahstana: yntegracyja nauky, obrazovanyja y proyzvodstva : materyal mezhd. nauchn.-prakt. konf. [Pharmacy Kazakhstan: integration of science, education and production: Materials of the international scientific-practical conference]. Shymkent, 2009, pp. 225-228. (in Russ.).

41. Williams Ch.A., Harborne J.B., Colasante M. Biochemical Systematics and Ecology, 1997, vol. 25, no. 4, pp. $309-325$.

42. Ysaev D.Y., Kerymov Ju.B., Kovalev S.V., Zatbl'nykova O.A. Farmakom, 2009, no. 4, pp. 45-48. (in Russ.).

43. Kovaleva A.M., Gorjachaja O.V., Yl'yna T.V., Sedova A.B. Vestnyk Permskoj gosudarstvennoj farmacevtycheskoj akademyy, 2013, no. 11, pp. 74-76. (in Russ.).

44. Kovalev S.V., Mikhailenko O.A., Kovalev S.V. Khimiia rastitel'nogo syr'ia, 2013, no. 3, pp. 201-205. (in Russ.)

45. Isaev D.I., Kerimov Iu.B., Kovalev S.V., Zatyl'nikova O.A. Farmakom, 2010, no. 1, pp. 38-42. (in Russ.).

46. Kovalev V.N., Zatyl'nikova O.A., Kovalev S.V. Khimiia prirodnykh soedinenii, 2013, no. 1, pp. 32-33. (in Russ.).

47. Kovalev V.N., Zatylnikova O.A., Kovalev S.V. Chemistry of Natural Compounds, 2013, vol. 49, issue 1, pp 34-35.

48. Zatyl'nikova O.O. Visnyk farmacii', 2012, no. 3 (71), pp. 57-59. (in Ukr.).

49. Koval'ov S.V., Osolodchenko T.P., Ahmedov E. Ju., Zatyl'nikova O.O. Visnyk farmacii', 2008, no. 3 (55), pp. 9-12. (in Ukr.).

50. Zatyl'nikova O.A., Kovalev V.N., Kovalev S.V. Rastitel'nye resursy, 2013, vol. 49, no. 2, pp. 233-240. (in Russ.).

51. Zatyl'nikova O.O., Kovalev V.N. Farmakom, 2009, no. 1, pp. 45-47. (in Ukr.).

52. Kovalev V.N., Mikhailenko O.A., Vinogradov B.A. Khimiia prirodnykh soedinenii, 2014, no. 1, pp. 143-144. (in Russ.).

53. Hohlova N.A., Derkach N.V., Zatol'nykova O.A Ukrai'ns'kyj biofarmacevtychnyj zhurnal, 2010, no. 3 (8), pp. $45-47$. (in Ukr.).

54. Likars'ki roslyny: [encykloped. dovid.]. [Medicinal plants: [encyclopedias. argument.]]. Kiev, 1990, 544 p. (in Ukr.).

55. Hohlova N.A., Derkach N.V., Zathl'nykova O.A., Kovalev V.N., Volkovoj V.A. Ukrai'ns'kyj biofarmacevtychnyj zhurnal, 2012, no. 1-2 (18-19), pp. 42-45. (in Ukr.).

56. Zatyl'nikova O.O., Osolodchenko T.P., Koval'ov V.M. Analy Mechnykovs'kogo Instytutu, 2010, no. 4, pp. $43-47$. (in Ukr.).

57. Hohlova N.A., Derkach N.V., Zatbl'nykova O.A., Kovalëv V.N., Volkova V.A. Ukr. biofarm. zhurn., 2012, no. 1-2, pp. 42-45. (in Ukr.).

58. Iakovlev G.P., Blinova K.F. Botaniko-farmakognosticheskii slovar'. [Botanyko-farmakohnostycheskyy dictionary]. Moscow, 1990, 192 p. (in Russ.)

59. Patent 2195307 (RU). 2002. (in Russ.). 
60. Takhtadzhian A.L., Fedorov A.A. Zhizn' rastenii v shesti tomakh. T. 6. Tsvetkovye rasteniia. [Plant life in six volumes. Volume 6. flowering plants]. Moscow, 1982, 543 p. (in Russ.).

61. Iordanov D., Nikolov P. Fitoterapiia. [Phytotherapy]. Sofia, 1970, 183 3. (in Russ.).

62. Evans W.C. Trease aand Evans. Pharmacognosy. 14-th Edition. London, 1996, 612 p. (in Russ.).

63. Nadaroglu Kh., Demir Ia., Demir N. Khimiko-farmatsevticheskii zhurnal, 2007, vol. 41, no. 8, pp. 13-18. (in Russ.).

64. Aslaniants L.K., Marshavina Z.V. Prikladnaia biokhimiia i mikrobiologiia, 1979, vol. 15, pp. 769-774. (in Russ.).

65. Aslaniants L.K., Marshavina Z.V., Kazarian A.G. Rastitel'nye resursy, 1988, vol. 24, pp. 107-110. (in Russ.).

66. Bagdasarova Z.M., Aslaniants JI.K., Uzunian L.V. Prikladnaia biokhimiia i mikrobiologiia, 1988, vol. 24, pp. 774-778. (in Russ.).

67. Shreter A.I. Lekarstvennaia flora sovetskogo Dal'nego Vostoka. [Medicinal Flora of the Soviet Far East]. Moscow, 1975, 327 p. (in Russ.).

68. Berkutenko A.Ia., Romanovskii S.S. Sovremennoe sostoianie i perspektivy nauchnykh issledovanii v zapovednikakh Sibiri. [Current state and prospects of scientific research in the reserves of Siberia]. Moscow, 1986, pp. 68-70. (in Russ.).

69. Blinova K.F., Kaliupanova N.I. Khimiia prirodnykh soedinenii, 1974, no. 4, p. 535. (in Russ.).

70. Blinova K.F., Glyzin V.I., Priakhina N.I. Khimiia prirodnykh soedinenii, 1977, no. 1, p. 535. (in Russ.).

71. Denisova O.A., Glyzin V.I., Patudin A.V., Gavrilenko B.D. Khimiko-farmatsevticheskii zhurnal, 1980, vol. 14, pp. 76-77. (in Russ.).

72. Fruentov N.K. Lekarstvennye rasteniia Dal'nego Vostoka. [Medicinal plants of the Far East]. Khabarovsk, 1987, 349 p. (in Russ.). 